\section{Mr. R. H. Hodgkin}

Mr. Robert Howard Hodgkin, who has been elected provost of Queen's College, Oxford, to succeed the late Canon Streeter, had retired from Oxford at the end of last term, relinquishing the position of senior history tutor of Queen's College, which he had held since 1910. Mr. Hodgkin is now in his sixty-first year. $\mathrm{He}$ was born at Newcastle-upon-Tyne on April 24, 1877, the son of Dr. Thomas Hodgkin, a banker and distinguished historian of Europe in the Middle Ages. Mr. Hodgkin was educated at Repton, Leighton Park School, Reading, and Balliol College, Oxford, taking first-class honours in the Final School of Modern History. He was appointed lecturer in modern history of Queen's College in 1900 ; and was University lecturer in modern history in 1928-34. His most considerable contribution to historical literature is his "History of the Anglo-Saxons" (1935), in which the scientific data of anthropology and archæology are drawn upon to the full to serve the purpose of historical research. Although a member of a distinguished Quaker family, Mr. Hodgkin held a sommission in the 1st V.B. Northumberland Fusiliers for some years, and thereupon was obliged to withdraw from the Society of Friends. During the Great War he served as captain in the Seventh Battalion of his old regiment, and on the General Staff (Operations) at the War Office.

\section{Evans' Biological Institute}

A COMPANY of some seventy-five medical men attended the Evans' Biological Institute at Runcorn, Cheshire, on October 7, when an extension was formally opened by Lord Derby. In introducing Lord Derby to the company, Mr. T. Edward Lescher directed attention to the fact that the organization known as Evans' Biological Institute is the result of continuous development during the last twenty-five years, and that it originated as a laboratory and farm station in connexion with the Liverpool Institute of Comparative Pathology under the rgis of the University of Liverpool. It was in 1903 that Prof. (afterwards Sir Rupert) Boyce, professor of pathology, and Prof. (now Sir Charles) Sherrington, professor of physiology, together with Dr. H. E. Annett, then lecturer on comparative pathology, conceived the idea of establishing a farm station at Higher Runcorn for the study of comparative pathology. Included in the committee of management was Mr. J. J. Evans, the first chairman of Evans Sons Lescher and Webb, Ltd., and his son Mr. J. H. E. Evans, who is the present chairman of the company. Shortly before the Great War, the University was compelled to relinquish activities at Runcorn, and the laboratories and farm station and laboratory personnel were taken over by the above firm. Although to some extent the activities were restricted during the War and for some years afterwards, valuable work was done and much experience gained. Gradually the scope of the work carried on was extended and accommodation increased, and in 1928 a commodious new building, containing up-to-date laboratories and equipment, was erected. Additional stables were erected in due course, and this year another new building has been completed.

DURING all these years, the work originated by the Liverpool Institute of Comparative Pathology has been continued at Runcorn along similar lines. A close study is made of the vital processes of living organisms, in the hope of evolving measures for the prevention of disease rather than the introduction of new palliative measures for use in treatment. In recent months the scope of the research work carried on at the Institute has been extended to chemotherapy, as it was discovered in 1935 that it is possible to control streptococeal infections by means of an important new drug intended for use in the treatment of various bacterial infections. The Institute is licensed under the Therapeutic Substances Regulations and thus is intimately linked with the Ministry of Health administration. Under these regulations, practically all the products with which the Institute is associated must maintain a very high standard. It has always been insisted upon that research and production should be conducted on strictly ethical lines, and no eonsideration has allowed any alteration to this policy. Lord Derby said that he felt it was a privilege to be associated with the opening ceremony, especially as in his office as chancellor of the University of Liverpool he knew those who were originally connected with the work. He looked forward to the research activities of the present staff leading to the introduction of still better ways of dealing with disease.

\section{Historical Relations of Pharmacy and Physic}

THE historical relation of pharmacy and physic was the subject of Sir Humphry Rolleston's address at the opening of the ninety-sixth session of the College of the Pharmaceutical Society. He showed how, in the field of medicine, as in most other fields, evolution has brought with it specialization, and that among the roots of the tree of medical knowledge is the legend of Cosmos and Damian, the patron saints whom pharmacy shares with medicine, surgery, barbery and midwifery as evidence of their common origin. The process of decentralization and specialization of medicine has been repeated at very different dates in the world's chronology. In Egypt medical specialism had reached its acme in the fifth century B.c. when every medical man confined his activities to one disease. On the other hand, in Europe it is difficult to trace a distinction between medical practitioners and the representatives of modern pharmacists until the approach of the Renaissance. In Great Britain, the process of specialization and separation was slow and painful. From so early 1447, the Grocers Company in the City of London had the right of inspecting shops for the sale of drugs, ointments and plasters, and its members were the recognized drug sellers of the day. From the specialist grocer the apothecary developed and in due time became a thorn in the flesh of the physicians, so that in 1540 the Royal College of Physicians obtained the power to "search, view and see the apothecaries' wares, drugs and stuffs". The apothecaries, balancing 
between trading and professionalism, temporarily came down on the wrong side of the fence, being united with the Grocers Company by charter in 1606 . But this inconvenient marriage was dissolved in 1617 , when the Society of Apothecaries obtained its own charter, James I saying that the apothecaries practised an art as well as a mystery, whereas the grocers were merely merchants.

THe apothecaries used their new freedom for still further specialization. They enhanced their reputation by devotion to the sick at the time of the Great Plague and rapidly developed into the general practitioners of medicine, a position ultimately recognized by registration under the Medical Act. They gradually abandoned pharmacy for physic and left the way open for the pharmacist as he is known to-day to take their place. Sir Humphry Rolleston did not follow the progress of specialization in recent years. Had he done so he might have shown how to-day, with the progress of medical science, specialization advances apace in both the medical and the pharmaceutical professions. In medicine, the physician and the surgeon find at their elbow the bacteriologist, the pathologist, the radiologist, the psycho-therapist. In pharmacy, the pharmacologist, the biochemist and the serologist are supplanting the galenical pharmacist. It is well for the patient, for whose benefit alone these 'mechanized troops' take the field, that so far they remain auxiliaries and have not yet displaced the 'private of the line'-the general practitioner and the pharmacist at the corner of the road.

\section{Flints and Flint-Working}

A sPECIAL exhibition to remain for three months has been arranged at the British Museum, Bloomsbury, at the head of the main staircase, to illustrate the changes in flint, and the various methods of chipping it into implements. This supplements the permanent series in the Prehistoric Saloon (Case R), and is intended to make the grammar of the subject doar to those with restricted opportunities of observing or collecting specimens. Patina has not yet been scientifically explained, but the examination of its varieties is a necessary step in solving the problem, and attention has been paid to the depths attamed by patina on several specimens. Some old pieces have been re-chipped by living practitioners; and among those whose skill is exemplified may be mentioned Mr. J. Reid Moir, Mr. J. H. Sewell of Saskatoon, M. Coutier of Paris and Prof. A. S. Barnes. Some peculiar forms assumed by flints when fractured by man or natural forces are exhibited, and the technical terms used in prehistory are illustrated by typical specimens. Drawings of flaking methods presumably practised in the Stone Age are reproduced from Warren K. Moorehead's "Stone Age in North America", and a special feature is the wood-technique (blows delivered by a wooden baton) which is believed to have been adopted by St. Acheul man, the long narrow flake-scars due to this method helping to distinguish work of that date from the preceding Chelles or Abbeville culture.

\section{Origins of Civilization and the Hittites}

THE early history of Anatolia and of the races from which the Turkish people is held to be derived was given due prominence in the communications presented by the numerous foreign members attending the second session of the Historical Congress at Istamboul. In particular, it is stated by the correspondent of The Observer in the issue of October 11, much importance was attached to a discussion by Prof. E. Pittard of Geneva of the origin of the early brachycephalic racial type, which, first appearing in Europe in the Mesolithic age, introduced to that continent the domestication of animals and agriculture. He pointed out that nowhere except in the Near East and in the region extending eastwards to Afghanistan were cereals to be found growing in the original wild state, while the same habitat was assigned to the wild prototypes of the domesticated animals. Prof. Pittard then went on to show that a close study of the Hittites indicated that all these elements of civilization were well known to them from early times, this leading to the supposition that we are indebted to this people for their evolution. Recent discoveries and excavations indicate a possibility of demonstrating that Anatolia possessed, just like Europe, a palæolithic period, from which the mesolithic was evolved, and that the remotest origins of civilization may be found in Anatolia. As the views put forward by Prof. Pittard are said to coincide with the point of view of the Turkish Society for Historical Research, it is possible that they will stimulate muchneeded intensive study of Hittite origins. It is eminently desirable, however, that this should be extended to include the Caucasus regions to the north of the Hittite area, with which certain of the evidence, especially of philology, appears to indicate a cultural affinity.

\section{Maiden Castle, Dorchester}

Two discoveries are announced at the close of the season's excavation of Maiden Castle, Dorchester, by the Society of Antiquaries and the Dorset Natural History and Archæological Society under Dr. R. E. Mortimer Wheeler and Col. C. D. Drew. The first is that of a long barrow of remarkable size, no less than eight hundred feet long, overlying the neolithic town, of which the remains have been identified at various points in the eastern part of the site. Evidently the village must wholly, or largely, have ceased to be occupied when this enormous tomb was constructed. Consequently, as is pointed out by Dr. Wheeler, according to a report in The Times of October 11, the discovery is of importance. The superposition of the neolithic barrow over the earlier neolithic town will make it possible to classify the successive phases of neolithic civilization in this part of Britain with greater precision than is possible at present, and it will thus afford a standard of chronological comparison for the interpretation of other neolithic settlements and mounds in this part of the country. The second discovery, which was made not far from the point at which the dismembered neolithic skeleton, previously reported, was found, was that 